\title{
COVID-19 in pregnancy: Italian experience
}

\author{
Nicola Volpe (ID), Giovanni Battista Luca Schera (iD), Tiziana Frusca \\ Obstetrics and Gynecology Unit, Department of Medicine and Surgery, University of Parma, Italy
}

\begin{abstract}
It has been happened a significant increase of critically severe pneumonia cases in northern Italy by the end of February 2020 with consequent overcrowding of intensive care units (ICU). Due to the COVID-19 fast outbreak, a strict quarantine was imposed in the areas with the higher number of affected cases. The WHO declared COVID-19 a pandemic, with over 50 countries on the 10th of March. By the 10th of March Italy was the second most affected country after China, with more than nine thousand confirmed cases and more than 460 deaths, becoming the most affected in April.
\end{abstract}

Keywords: Coronavirus SARS-2, pregnancy, outcome.

\section{Özet: Gebelikte COVID-19: İtalyan deneyimi}

Şubat 2020 sonu itibarıyla kuzey İtalya'da, kritik derecede şiddetli pnömoni olgularında önemli bir artış gerçekleşti ve bunun sonucunda yoğun bakım ünitelerinde (YBÜ) aşırı yoğunluk meydana geldi. Hızlı COVID-19 salgını nedeniyle, hastalıktan etkilenen yüksek sayıda olgunun olduğu bölgelerde katı bir karantina uygulandı. Dünya Sağlık Örgütü, 10 Mart'ta 50'den fazla ülkede COVID-19'u küresel salgın olarak ilan etti. 10 Mart itibarıyla İtalya, teyit edilmiş dokuz binden fazla olgu ve 460'ın üzerinde ölüm ile Çin'den sonra en çok etkilenen ikinci ülkeyken, Nisan ayında en çok etkilenen ülke oldu.

Anahtar sözcükler: Koronavirüs SARS-2, gebelik, sonuç.
The current coronavirus disease (COVID-19) is a new systemic inflammatory disease caused by the Severe Acute Respiratory Syndrome Coronavirus 2 (SARSCoV-2), identified for the first time in December 2019, in Wuhan, China. ${ }^{[1,2]}$ This virus quickly spread across the rest of the country and progressively outside, such to be declared as a Public Health Emergency of International Concern (PHEIC) by the Pan American Health Organization / World Health Organization (PAHO/WHO) on the 30th of January.

By the end of February 2020, the virus spread in northern Italy (mainly Lombardy, Veneto and EmiliaRomagna), leading to a significant increase of critically severe pneumonia cases in these areas, with consequent overcrowding of intensive care units (ICU). As the number of deaths rapidly increased, due to the COVID-19 fast outbreak, a strict quarantine was imposed in the areas with the higher number of affect- ed cases, in order to minimize the chance of contagion. From the 9th of March 2020, quarantine was extended to the whole country, with inhibition of travels within and between regions, and a complete lockdown of schools, industries and productive activities with the exception of hospitals and other essential activities (food shops, pharmacies, etc.). Meanwhile, on the 10th of March the WHO declared COVID-19 a pandemic, with over 50 countries involved. Despite these preventive measures, contagion curve exponentially increased in Italy, and within few days a total lockdown was imposed. By the 10th of March Italy was the second most affected country after China, with more than 9 thousand confirmed cases and more than 460 deaths, becoming the most affected in April. ${ }^{[3]}$

SARS-CoV-2 is transmitted predominantly via respiratory droplets, contact and fecal-oral routes. ${ }^{[4]}$ It has been reported that coronavirus cell invasion is mediat-

\footnotetext{
Correspondence: Nicola Volpe, MD. Obstetrics and Gynecology Unit, Department of Medicine and Surgery, University of Parma, Italy. e-mail: volpe.prenatal@gmail.com / Received: June 13, 2020; Accepted: June 15, 2020

Please cite this article as: Volpe N, Schera GBL, Frusca T. COVID-19 in pregnancy: Italian experience. Perinatal Journal 2020;28(3):149-153. doi:10.2399/prn.20.0283001
} 
ed by specific receptor-binding virus domains interacting with the angiotensin-converting enzyme 2 (ACE2) receptor. ACE2 receptor is usually expressed in upper and lower respiratory epithelium, but it may be also found in the heart, esophagus, kidney, stomach, bladder and ileum. Once invasion has occurred, viral replication leads to a mild viremia, with generally mild flulike symptoms and diffusion of the virus (stage I). A subsequent involvement of the lung often occurs, in the stage II or pulmonary phase of the illness, with the development of a viral pneumonia, and cough, fever and progressive hypoxia as main symptoms. ${ }^{[5]}$ The viral response progressively reduces, whereas the host inflammatory response increases, leading in a minority of patients to the stage III or hyperinflammation phase, with a progression of the pneumonia to acute respiratory syndrome, and systemic hyperinflammation syndrome, involving also extra-pulmonary tissues. ${ }^{[5]}$ In this phase, septic shock, cardiac and multiorgan failure may also occur in the worst cases. The biological mechanism leading to a disease state includes direct endothelial and vascular damage with subsequent exuberant local and systemic inflammatory response mediated by cytokines and chemokines. Complement activation and angiotensin subtypes seem to be also involved, leading to hypercoagulability and microangiopathy. ${ }^{[6]}$ Even a possible underlying mechanism of antibody-dependent enhancement promoting an increase of inflammatory responses and persistent viral replication was proposed. Moreover, immune dysfunction with overactivation and reduction of $\mathrm{T}$ cells contribute to pathogenesis. ${ }^{[4,7]}$ Nasopharyngeal swabs detect the presence of the virus in only $80 \%$ of affected patients, whereas high resolution computed tomography seems more accurate in detecting the pulmonary involvement, showing a ground-glass opacity, commonly related to COVID19. ${ }^{[8]}$ Moreover, lymphopenia appears to be a common finding in the earlier stages of the disease, whereas elevated inflammatory markers (C-reactive protein and pro-inflammatory cytokines, ferritin) may be found later.

Treatment of COVID-19 patients has been subject of controversies. ${ }^{[9]}$ The main therapies proposed include anti-viral drugs such as remdesivir, antibiotics such as azithromycin, immunosuppressive drugs such as tocilizumab, chloroquine/hydroxychloroquine, corticosteroids, and more recently also plasma from con- valescent patients. ${ }^{[9,10]}$ However, their efficacy against the novel coronavirus has not been definitively proven yet and treatment should be tailored to the patient's characteristics and disease stage. In particular, LMW heparin has been quite often used for its anticoagulant as well as immunomodulatory properties.

Recent evidences demonstrate that mean incubation period is $3-5$ days, ranging from 0 to 24 days, but the first symptoms usually appear within 14 days after exposure. ${ }^{[1]}$ During this incubation period, the virus usually replicates in the upper airways, with the chance of transmission also for asymptomatic. ${ }^{[1,12]}$ Therefore, Italian health authorities recommended a 14-days quarantine in case of close contact with affected people, and after the end of symptoms for ascertained or suspected COVID-19. After quarantine, a nasopharyngeal swab is recommended to ensure a negative result.

In pregnant women, COVID-19 early symptoms are similar to those described in general population, with fever and cough occurring in the majority of cases. In a systematic review for pregnant patients, authors described an incidence of $48 \%$ and $46 \%$, respectively. Less frequent symptoms included sore throat, fatigue, myalgia, diarrhea. However, the majority of infected cases $(69 \%)$ are asymptomatic. ${ }^{[13]}$ When the viral pneumonia occurs, the pregnant patient usually develops severe hyperpyrexia, cough and dyspnea, similarly to what occurs in the general population..$^{[13,14]}$ Nonetheless, the proportion of asymptomatic pregnant patients infected by SARS-CoV-2 has not been definitely assessed. Although pregnant women seem more likely to develop severe illness after respiratory viruses' infection due to the pregnancy-related changes of their immune and cardiopulmonary systems, ${ }^{[15]}$ in case of COVID-19 current evidences show that the course of the disease is not so severe as we could expect, with a very low mortality rate. ${ }^{[1,17]}$ Moreover, the incidence of infection in pregnant women seems to be lower than in general population. Various explanation had been given, related to the lower mean age of pregnant women ${ }^{[18]}$ and the shift of immune response from T1 to T2. ${ }^{[19-21]}$ Data about the impact of COVID19 on the fetus are still scarce due to the fact that most infected women included in literature were at higher gestational age and no clear evidence of placental transmission has been yet demonstrated. On the contrary, similar infections (Middle East Respiratory syn- 
drome or MERS and Severe Acute Respiratory Syndrome or SARS) have shown increased fetal morbidity and mortality. ${ }^{[2]}$ Recent retrospective studies have shown higher incidence of premature birth in COVID-19 pregnant patients, even if mainly iatrogenic, as the option of an anticipated delivery is often considered when maternal conditions worsen. ${ }^{[13,14,23]}$

Treatments proposed for COVID-19 are not contraindicated in pregnancy. However, the option of an anticipated delivery in case of disease seems the most challenging decision for the obstetrician, as mentioned. The timing of delivery should take in account both the gestational age and the actual clinical condition of the mother. In case of severe disease in advanced gestational ages, immediate delivery could improve maternal breathing and avoid the risk of hypoxia for the fetus, with low risks of prematurity complications. At earlier gestational ages the risk of prematurity is higher, and the option of delivery should be carefully considered. The mode of delivery most frequently reported is the caesarean one, ${ }^{[13]}$ even if national ${ }^{[24]}$ and international societies support vaginal delivery. ${ }^{[15,25]}$ The transmission during vaginal delivery has not been clearly demonstrated and the virus has not yet been detected in vaginal swabs. A post-partum contact may be an underlying cause of the few reported cases of neonatal infection. ${ }^{[14]}$ Moreover, breastmilk seems not to be involved in virus as the virus has not been detected in the milk. Although breastfeeding is strongly suggested, care must be taken in order to prevent direct contact with the infected mother who should wear a surgical mask during the feeding. In severe cases, breast milk pumping should be considered. $^{[14,15]}$

In northern Italy, the sudden diffusion of the virus required a quick redistribution of the health system resources. In particular, new recommendations for obstetric vigilance and management were provided at local and regional levels, aiming to keep good standards of care and safety for pregnant women. ${ }^{[18]}$ According to the most used strategy, the centralization of pregnant patients and specialized healthcare personnel was provided in tertiary centers or "hub" hospitals, whereas smaller hospitals became exclusively dedicated to COVID-19 patients. Centralization was supported by the availability of better equipment and multidisciplinary experience in tertiary centers, with greater safe- ty for operators and patients. Although this policy was generally accepted, there have been criticisms about the centralization of cases in "hub" hospitals which were overcrowded and not prepared to the elevated number of patients. Moreover, many caregivers pointed out several pitfalls in the network of local health services and complained about the lack of clear instructions and low availability of personal protective equipment (PPE), especially during the early stages of the emergency in Italy. This has probably been one of the reasons of the very high mortality rate due to COVID19 in Lombardy, and justifies the important debate about the policy undertaken by the regional health institutions.

Due to this reorganization, "hub" hospitals modified their clinical activity according to the new COVID-19 emergency, providing only activities which could not be postponed (oncological activities, urgent surgeries, etc.), whereas gynecological screenings, benign surgery and assisted reproductive technology were suspended. Non-urgent pregnancy visits, routine ultrasound scans and invasive testing have been postponed for patients infected by $\mathrm{CoV}-2$. Workflow was reprogrammed to reduce as much as possible the risk of virus diffusion between patients and health workers, and among patients. This was accomplished through the reorganization of appointments, with a longer time allowed for each visit in order to avoid patients' grouping in waiting rooms.

A dedicated COVID-19 triage area is recommended, based on symptoms (fever, cough, dyspnea, etc.) and other risk factors (travel, occupation, contacts and cluster), in order to perform a nasopharyngeal swab to high-risk cases, keeping separated paths and areas for COVID-19 patients. For those with suspected or diagnosed COVID-19, the definition of designated isolation areas is recommended, including dedicated waiting areas, beds, delivery room and operating theatre. Moreover, PPE was distributed and adopted if necessary, after adequate training about its use and removal.

In conclusion, the COVID-19 emergency caused an exponentially increasing number of deaths in Italy during the first weeks of coronavirus pandemic. This can be probably related to the quick spread of the virus among northern Italy population, due to the long incubation period and the high transmission rate of the novel coronavirus. Moreover, the elevated number of 
infected people needing hospitalization was not expected, with the health system unable to promptly react to this emergency. This led to a quick overcrowding of the ICUs and consequently to the difficulty to treat critical patients in an optimal way. The ongoing controversies on drugs potentially useful for COVID19 furtherly worsened the scenario and the number of deaths, finally reduced only after introducing the strict lockdown, a preventive rather than treating strategy. In pregnant women, the disease seems less severe than previous coronavirus-related syndromes, but few critical issues need to be furtherly clarified.

Conflicts of Interest: No conflicts declared.

\section{References}

1. Zhu N, Zhang D, Wang W, Li X, Yang B, Song J, et al.; China Novel Coronavirus Investigating and Research Team. A novel coronavirus from patients with pneumonia in China, 2019. N Engl J Med 2020;382:727-33. [PubMed] [CrossRef]

2. ECDC Technical Report. Infection prevention and control for the care of patients with $2019-\mathrm{nCoV}$ in healthcare settings. [Internet]. Stockholm: ECDC. [2020 February 2]. Available from: https://www.ecdc.europa.eu/en/publications-data/infection-prevention-and-control-and-preparedness-covid-19healthcare-settings

3. World Health Organization (WHO). Coronavirus disease (COVID-2019) situation reports. [Internet]. Geneva: WHO. [uptaded 2020 March 10; cited 2020 April]. Available from: https://www.who.int/emergencies/diseases/novel-coronavirus2019/situation-reports

4. Jin $\mathrm{Y}$, Yang $\mathrm{H}, \mathrm{Ji} \mathrm{W}, \mathrm{Wu} \mathrm{W}$, Chen $\mathrm{S}$, Zhang $\mathrm{W}$, et al. Virology, epidemiology, pathogenesis, and control of COVID-19. Viruses 2020;12:372. [PubMed] [CrossRef]

5. Siddiqi HK, Mehra MR. COVID-19 illness in native and immunosuppressed states: a clinical-therapeutic staging proposal. J Heart Lung Transplant 2020;39:405-7. [PubMed] [CrossRef]

6. Batlle D, Soler MJ, Sparks MA, Hiremath S, South AM, Welling PA, et al. Acute kidney injury in covid-19: emerging evidence of a distinct pathophysiology. J Am Soc Nephrol 2020;31:1380-3. [PubMed] [CrossRef]

7. Rothan HA, Byrareddy SN. The epidemiology and pathogenesis of coronavirus disease (COVID-19) outbreak. J Autoimmun 2020;109:102433. [PubMed] [CrossRef]

8. Ng MY, Lee EYP, Yang J, Yang F, Li X, Wang H, et al. Imaging profile of the COVID-19 infection: Radiologic findings and literature review. Radiology: Cardiothoracic Imaging 2020;2:e200034. [CrossRef]

9. Farfán-Cano GG. A perspective about Coronavirus Disease 2019 (COVID-19). INSPILIP Digital Scientific Journal 2020; 4:1-21.
10. Yi Y, Lagniton PNP, Ye S, Li E, Xu RH. COVID-19: what has been learned and to be learned about the novel coronavirus disease. Int J Biol Sci 2020;16:1753-66. [PubMed] [CrossRef]

11. Li Q, Guan X, Wu P, Wang X, Zhou L, Tong Y, et al. Early transmission dynamics in Wuhan, China, of novel coronavirus-infected pneumonia. N Engl J Med 2020;382:1199207. [PubMed] [CrossRef]

12. Guan WJ, Ni ZY, Hu Y, Liang WH, Ou CQ, He JX, et al.; China Medical Treatment Expert Group for Covid-19. Clinical characteristics of Coronavirus Disease 2019 in China. N Engl J Med 2020;382:1708-20. [PubMed] [CrossRef]

13. Gatta AND, Rizzo R, Pilu G, Simonazzi G. Coronavirus Disease 2019 during pregnancy: a systematic review of reported cases. Am J Obstet Gynecol 2020;223:36-41. [PubMed] [CrossRef]

14. Ferrazzi E, Frigerio L, Savasi V, Vergani P, Prefumo F, Barresi S, et al. Vaginal delivery in SARS-CoV-2-infected pregnant women in Northern Italy: a retrospective analysis. BJOG 2020 Apr 27;10.1111/1471-0528.16278. [PubMed] [CrossRef]

15. Royal College of Obstetricians \& Gynaecologists (RCOG). Coronavirus (COVID-19) Infection in pregnancy. Information for healthcare professionals. Version 10. [Internet]. London: RCOG. [2020 June 4]. Available from: https://www.rcog.org. uk/globalassets/documents/guidelines/2020-06-04-coronavirus-covid-19-infection-in-pregnancy.pdf

16. Mullins E, Evans D, Viner RM, O’Brien P, Morris E. Coronavirus in pregnancy and delivery: rapid review. Ultrasound Obstet Gynecol 2020;55:586-92. [PubMed] [CrossRef]

17. Poon LC, Yang H, Kapur A, Melamed N, Dao B, Divakar $\mathrm{H}$, et al. Global interim guidance on coronavirus disease 2019 (COVID-19) during pregnancy and puerperium from FIGO and allied partners: information for healthcare professionals. Int J Gynaecol Obstet 2020;149:273-86. [PubMed] [CrossRef]

18. Ferrazzi EM, Frigerio L, Cetin I, Vergani P, Spinillo A, Prefumo F, et al. COVID-19 Obstetrics Task Force, Lombardy, Italy: executive management summary and short report of outcome. Int J Gynaecol Obstet 2020;149:377-8. [PubMed] [CrossRef]

19. Zhao X, Jiang Y, Zhao Y, Xi H, Liu C, Qu F, et al. Analysis of the susceptibility to COVID-19 in pregnancy and recommendations on potential drug screening. Eur J Clin Microbiol Infect Dis 2020;39:1209-20. [PubMed] [CrossRef]

20. Jackson DJ, Busse WW, Bacharier LB, Kattan M, O'Connor GT, Wood RA, et al. Association of respiratory allergy, asthma, and expression of the SARS-CoV-2 receptor ACE2. J Allergy Clin Immunol 2020;146:203-6.e3. [PubMed] [CrossRef]

21. Maggi E, Canonica GW, Moretta L. COVID-19: Unanswered questions on immune response and pathogenesis. J Allergy Clin Immunol 2020;146:18-20. [PubMed] [CrossRef]

22. Di Mascio D, Khalil A, Saccone G, Rizzo G, Buca D, Liberati $M$, et al. Outcome of Coronavirus spectrum infections (SARS, MERS, COVID-19) during pregnancy: a systematic review 
and meta-analysis. Am J Obstet Gynecol MFM 2020;2:100107. [PubMed] [CrossRef]

23. Balakrishnan A, Loh MH, Tan CH, Su LL, Young BE, Lye DC, et al. Care of the pregnant woman with Coronavirus Disease 2019 in labor and delivery: anesthesia, emergency cesarean delivery, differential diagnosis in the acutely ill parturient, care of the newborn, and protection of the healthcare personnel. Am J Obstet Gynecol 2020;223:66-74.e3. [PubMed] [CrossRef]
24. Ministero della salute. Circolare ministeriale Prot. n 0011257-31/03/2020. COVID-19: indicazioni per gravida-partoriente, puerpera, neonato e allattamento. [Internet]. Rome: Ministry of Health. Available from: http://www.salute.gov.it/ nuovocoronavirus

25. The American College of Obstetricians and Gynaecologists (ACOG). Novel Coronavirus 2019 (COVID19). [Internet]. Washington, DC: ACOG. [cited 2020 April]. Available from: https://www.acog.org/clinical/clinical-guidance/practiceadvisory/articles/2020/03/novel-coronavirus-2019

Bu makalenin kullanım izni Creative Commons Attribution-NoCommercial-NoDerivs 3.0 Unported (CC BY-NC-ND3.0) lisansı aracılığılyla bedelsiz sunulmaktadır. / This work is licensed under the Creative Commons Attribution-NonCommercial-NoDerivs 3.0 Unported (CC BY-NC-ND3.0) License. To view a copy of this license, visit http://creativecommons.org/licenses/by-nc-nd/3.0/ or send a letter to Creative Commons, PO Box 1866, Mountain View, CA 94042, USA. 